therefore continued to attend conferences and undertake speaking engagements, as well as continuing research projects. One of the newer research projects involves an attempt to understand the "aid relationship", which involves the problems of how donor and recipient can best work together.

Mr Clark's successor as director at the ODI is $\mathrm{Mr}$ Anthony Tasker, who took over in May this year. Most of his career has been spent as a representative of the Booker Group of companies in Guyana, and from 1957 to 1964 he was a member of the British Guiana legislature. Before joining the Booker Group, Mr Tasker was organizing director of the International Tea Market Expansion Board. He is experienced in the marketing problems of the developing countries, which should be valuable in his new job. Too often it has been glibly assumed that developing countries are willing to accept whatever they were told was good for them, particularly if it is free. Many a protein supplement has foundered because of inadequate marketing. It is true that the ODI so far shows no signs of going into the business of manufacturing protein supplements, but marketing experience is likely to be of increasing relevance in overseas aid. There will be genuine regret at William Clark's departure, because it was he who launched the ODI in 1960 and has sustained it since. As director of information and public affairs at the World Bank, he hopes to continue the work begun at ODI, but translated into the international field.

\section{RESEARCH Who Does What}

The Department of Education and Science and the British Council have once again produced their guide to Scientific Research in British Universities and Colleges, 1967-68 (HMSO, Vol. 1: Physical Sciences, $£ 2$ 5s.; Vol. 2: Biological Sciences, £2 5s.; and Vol. 3: Social Sciences, £2). Like the volumes for 1966-67, this new edition comes at the end of the academic year to which it relates, which means that many of the entries will be already out of date. Nevertheless, the books serve a very useful purpose.

Some of the inconsistencies and irritations in the earlier edition still persist. For example, the character of the descriptions of the research projects varies from one university to another-some spell out what each individual member of a department does, and some still lump all the projects together. To some extent, inconsistencies are inevitable because the compilers rely on the cooperation of the individual institutions, but this is no reason why several archaeological departments are not included at all.

Changes include new sections for Animal Husbandry (Vol. 2) and for Criminology (Vol. 3). The heading Mental Health in Vol. 3 has been altered to Psychiatry. The split between physical geography and human geography (the first is in Vol. 1 and the second in Vol. 3) is now very much clearer for the user.

The principal changes appear to be in the third volume which, like the volume for 1966-67, continues to include several non-university institutions. This time there are new entries for the Advisory Service for the Building Industry, British Institute of Management, BOAC, Heating and Ventilating Research Association, Library Association, Newcastle upon Tyne
Regional Hospital Board, and the Overseas Development Institute, to name a few. The subject index remains a little inconsistent, with some categories defined very precisely, while others are much broader.

\section{POLLUTION \\ New Laws for Pesticides}

The US Federal Drug Administration announced recently that the amount of DDT allowed to remain on food sent to market is to be significantly reduced after January 1, 1969; for some crops the levels have been reduced by 50 per cent, and more than half of all the fruit and vegetables sold in the US will be affected. In Britain the Ministry of Agriculture has just sent its proposals for a new Pesticides Bill to well over 100 organizations representing the food, agriculture and chemical industries as well as to medical veterinary and animal protection organizations, for their comments. Both steps are indicative of increasing government concern over the accumulation of pesticides in food.

The aim of the proposed new Pesticides Bill is to tighten up controls on the sale and use of pesticides by covering in a single piece of legislation their licensing, use, and permitted limits of residues in foodstuffs. If the proposals become law, all pesticides will have to be licensed by a new Licensing Authority comprising the Ministers of Agriculture and Health, the Secretary of State for Scotland and appropriate ministers in Northern Ireland. The authority will receive the technical assistance of an Advisory Committee similar to the existing Advisory Committee on Pesticides and Other Toxic Chemicals, on whose report the new Bill is chiefly based. (The report of the existing advisory committee on the present safety arrangements for the use of toxic chemicals in agriculture and in food storage is apparently to be published shortly.)

Enforcement of the new licensing regulations would be the responsibility of the Weights and Measures authorities and they would examine about 200 licensed. products a year, analysing samples and ensuring they were up to standard. The new Bill would lay down penalties for using pesticides on crops for which they were not intended, deliberately using overdoses or using dressed seed as animal food. All users of pesticides would be required to keep records of the amounts purchased, how much was used and on what crops. All pesticides would have to be stored separate from seed, fertilizer or produce. The Bill would also extend the protection necessary for workers engaged in applying pesticides and include for the first time under these provisions persons involved in food storage and the self employed. The ministers would be able to enforce residue limits in produce, irrespective of any immediate hazard to consumers. This would provide an additional check on the levels of pesticides used in the field.

If these proposals become law, they will provide much more stringent control of pesticides in Britain. Much will hang on how they are enforced, and that in turn will depend on the voluntary acceptance of the legislation by the agricultural industry, but to encourage this the Bill makes provision for the appointment of inspectors with the same powers of entry as those included in the Agriculture (Poisonous Substances) Act of 1952. 